\title{
Sound System Performances and the Localization of Dancehall in Finland
}

\author{
Kim Ramstedt \\ Åbo Akademi University, Turku, Finland \\ kim.ramstedt@abo.fi
}

\begin{abstract}
This study examines how the particular performance practices associated with reggae music have contributed to the localization of dancehall culture in Finland. At the core of this culture lies the concept of the sound system, which, in addition to a DJ, includes a master of ceremonies, or $\mathrm{MC}$, who during a performance, in various ways, interacts with the audience. This article is especially concerned with how Finnish sound systems localize through their performances a particular understanding of reggae as a genre in Finland, and promote reggae as what I define as the dancehall continuum. Theoretically, this study draws on the study of folklore as performance and on sociological genre theory. The empirical material consists of interviews with sound system operators and discussions on an Internet message board. Additionally, a close reading of the written history of reggae is conducted. The study shows that Finnish sound systems do not only act as intermediaries of Jamaican music, but engage the local audience in the creation of a particular adaptation of dancehall culture in Finland.
\end{abstract}

Keywords: dancehall, Finland, Jamaica, localization, performance, reggae

\section{Introduction}

To understand the dance hall system is to understand many of the mysteries of reggae [...] If you have once stood in the middle of a sound system when the speakers are blasting the latest dub plate, you understand reggae much more profoundly than listening to it from your home hi fi for years and years. (Kaski and Vuorinen 1984: 5)

As Finnish reggae enthusiasts Kaski and Vuorinen (1984) suggest in their influential documentation of dancehall culture in Jamaica, understanding the logic of the sound system performance tells us a lot about reggae music. This article examines the localization of reggae in Finland through the particular performance practices associated with dancehall culture. At the core of this culture is the concept of the sound system, which in its essence consists of a DJ or selector who selects the recordings to play, and an MC (master of ceremonies) or toaster, who in various ways will seek to interact with the audience during a performance. Traditionally in Jamaica and its diaspora, the customized sound equipment and speaker systems of each sound system have been material in their appeal to the audience. However, at least in Finland, current sound systems are mostly associated with the selectors and MCs as performers, their cultural capital and repertoire of music.

The significance of the Jamaican sound systems in the formation and progress of reggae is acknowledged in most histories of the music (Barrow and Dalton 2001; Bradley 2001; Katz 2003; Stolzoff 2000). The sound system and its particular performance style is considered an institution within popular music and its influence on 
musical forms in the Jamaican diaspora of North America and the UK, and on club culture in general, is widely recognized (Henriques 2011; Manuel and Marshall 2006; Veal 2007). Although reggae music and the sound system practice have received a substantial amount of scholarly attention, most studies have focused on the culture in Jamaica and its diaspora. With the exception of Marvin D. Sterling's (2010) thorough ethnography of African-Jamaican popular culture in Japan, the expanding attraction of reggae and dancehall culture in other parts of the world has largely been overlooked. By studying the performance practices of local sound systems in Finland, I aspire with this article to fill some of this gap.

My research explores the impact local sound systems have on the localization of reggae music in Finland. Two aspects of the sound system performance are specifically in focus. First, I will look at the role of the $M C$ as narrator of the performance and then consider the selector's choice of Jamaican repertoire and the use of exclusively commissioned recordings called dubplates, which are unique versions of original mixes, customized for the specific selector and their sound system. Hereby, the study seeks to identify what kind of narrative about reggae as a genre is localized in Finland through the sound system practice. This is done in the last part of this paper in comparison with how reggae initially reached Finland through the global music industry. Theoretically the study draws foremost on the study of folklore as performance (Bauman 1975, 1986), and sociological genre theory (Fabbri 1982, Frith 1998). The empirical material in this study includes interviews with sound system operators and promoters in the cities of Helsinki and Turku conducted between 2008 and 2010, and discussions on an online Finnish reggae forum from the same period. Additionally, a close reading is conducted of previous research on reggae and the genre's global dissemination.

Although I will discuss the concepts of reggae and dancehall, and how the definition of these terms is negotiated among the local audience, a few general points should be made clear here, which also define the ethnographic field I am concerned with. Dancehall is an ambiguous term, which depending on the context can mean different things, signifying either a particular style of reggae music or its performance context. I use dancehall foremost to refer to music performed by sound systems, which can include a number of different musical styles, normally placed under the umbrella term reggae. This mostly includes, but is not limited to, different musical styles that have emerged from the Jamaican dancehalls where sound systems perform, such as ska, rock steady, roots reggae, dub, and dancehall - all of which I will define as being components of a dancehall continuum.

Here, the difference between reggae and dancehall is primarily defined ontologically, placing the centre of attention either in the sound system performance or in the live performance and music recording respectively. Dancehall denotes music performed by sound systems, whereas reggae refers to the generic musical styles developed in the context of the Jamaican sound system performances, but is not concerned with their mediation. The research is consequently limited to reggae music as it is performed by sound systems, and is, despite certain genre specific parallels, not concerned with live reggae performed by bands in Finland. Nevertheless, the focus on sound system activities is not as narrow as it may seem in describing the localization of reggae music in Finland, as most of the reggae events that offer live acts are also organized by local sound system crews.

It should be noted that, in Finland, audiences frequently talk about the dichotomy between, on the one hand, roots reggae, the relaxed tempo of traditional reggae characterized by its typical off-beat ostinato that is associated with the live reggae circuit and, on the other hand, the sound of digital dancehall reggae that is associated with sound systems and club culture. However, most sound systems in Finland perform a range of Jamaican dancehall derived music styles - some identifying closely with a particular subgenre, others aiming for a more all around interpretation of African- 
Jamaican music. Concerning the different ways of interpreting the notions of reggae and dancehall, in this paper the context will hopefully clarify if reference is made to the music as a particular sound or to the music's ontological character and mediation.

I will begin by discussing the MC's role in the performance, after which I will briefly look at sound systems' choice of musical repertoire. In the last part of this article, I will study audience comments online and look at what kind of narrative of reggae as a genre is localized in Finland through the sound system performance. This is contrasted with how reggae initially reached audiences in Finland through the sound recording industry, and what kind of idea about the music this process entailed.

\section{The MC and the performance form}

As this study is concerned with how a particular musical culture is localized through performances, I have found it fitting to employ Richard Bauman's (1975; 1986) theory of folklore as performance. According to Bauman, folklore should be studied as performance, highlighting the ways in which, or how, a content is communicated, rather than analysing the mediated text as a fixed object. Bauman highlights the usefulness of the notion of a frame as a way of organizing social experiences. In a performance, framing is a form of metacommunication, informing the audience about the occurring performance, enabling them to place it in its proper context. Fundamental in the framing of a performance, according to Bauman (1975: 293) is the "assumption of responsibility to an audience for a display of communicative competence". For a performance to work, it is important that the audience expectations and understanding of the performance form meet the performer's intentions.

As Simon Frith (1998: 209) notes, performance in this sense is "a way of standing back from content and considering form". I will here approach the MC's role in the performance primarily as a way of framing the content of the sound recordings to the performance setting. Julian Henriques (2011: 175-186) suggests that in a Jamaican sound system performance the task of the $M C$ is to guide, excite and control the crowd $^{1}$. I want to look at how a local Finnish MC can accomplish these tasks when the performance form of the sound system is not part of the local tradition and not innately familiar to local audiences.

Two aspects of Bauman's notion of framing are useful in understanding the MC's role in this regard. First of all, Bauman (1975: 295) maintains that framing is about employing "culturally conventionalized metacommunication" informing the audience how to interpret the text being communicated. Relevant here is how a "culturally conventionalized" form is transferrable to a different context or culture. The other important point that Bauman (ibid. 297) identifies in verbal art in terms of an interpretative frame is that it can vary in intensity: "Art is commonly conceived as an allor-nothing phenomenon - something either is or is not art - but conceived as performance, in terms of an interpretive frame, verbal art may be culturally defined as varying in intensity as well as range." How does the MC's performance relate to conventions of everyday conversation in the culture where it is performed?

In order to answer this, we need to recognize that the sound system performance is connected to the particular orality of Jamaican culture. As Henriques (2011: 8) maintains, storytelling and the sound of the spoken word have been key elements in the "richly expressive dramatic performance of everyday Jamaican culture". Henriques contrasts this tradition with other Caribbean islands were newspapers, poems, literature, other written forms, and painting have had a more prominent role in popular culture. The particular orality of Jamaican culture can also be found in the MC. At a sound system performance in Finland, you would normally hear an MC use these Jamaican speech forms. Speaking English, or Jamaican Creole during a performance, the MC uses expressions from dancehall culture, "bigging up" artist and places, "blessing" their performance with a "lord "ave mercy" and asking the audience "wha 
gwan". Coming from a native white Finn, these expressions can seem superimposed, yet they are widely used. Frith (1998: 209) has identified the speaking behaviour of African-American and African-Caribbean communities as the most "significant linguistic source of performing conventions" for contemporary popular music. The ubiquity of these linguistic forms in urban popular culture has also made them familiar to the nonAnglophonic audiences of Finland. However, the absence of these forms in the everyday Finnish speech emphasizes the performative aspect in the spectrum of intensity that Bauman discerns between conversational speech and performance.

In its original African-Jamaican context, the use of such seemingly performative expressions is culturally embedded. As Jones (1988: 41) notes, Jamaican English has been important in reaffirming a Caribbean identity in its diaspora. In Finland, with a relatively low immigrant rate, and almost no Caribbean diaspora, this practice is not culturally conventionalized, and, thus not straightforward understood as a natural part of the performance. Consequently, rather than making the performance through its conversational nature easy to approach, applying expressions and forms from another culture can make the performance overacted. These speech forms' detachment from the performance of the everyday in Finnish culture can make them seem out of place in sound system performances in Finland.

One way the MC can avoid the misplacement of the Jamaican "dramatic performance of everyday" (Henriques 2011) in Finland, is to perform in the local Finnish language. However, as MC Chappa (Mikko Näppä) from the Helsinki-based Forward Squad sound system suggested during an interview in 2010, this requires a greater degree of innovation from the MC. As the lyrics in the imported recordings do not directly translate to Finnish, the MC has to work his way around the concepts and come up with novel expressions in Finnish. The songs that Finnish sound systems play are almost exclusively in English or Jamaican Creole, which makes it easier for the MC to pick up lyrics from a song in English and connect them to the performance setting. Chappa normally uses English when he is performing in the larger cities of southern Finland, but he has noticed how rural audiences do not respond as well to an English performance. Consequently, he has chosen to perform in Finnish in the smaller cities of rural Finland. According to Chappa, these performances tend to be livelier: "The crowd is in a way more honest, they are into the thing in a special way" (2010, Helsinki). Chappa thought this would be because there were fewer reggae events in rural Finland and fans there can be more excited than a metropolitan crowd when a sound system event occurs. However, building on the theoretical framework here, it could also be suggested that by using Finnish, the MC can more naturally connect with the local audience. As the conversational nature of the performance is highlighted, the crowd can more easily be guided and excited. The here and now, the atmosphere and local presence at the performance event is emphasized, at the expense of particularities in the Jamaican dancehall culture that the performance seeks to convey.

Regarding the choice of language, in broader terms, a native Finnish MC has to balance between a seemingly superimposed expression in English or Jamaican Creole with a more local conversational delivery in the Finnish language. The crucial issue here is, as Frith (1998: 210) notes, whether the performer means it. Does the performer and the performance seem authentic and is it believable to the audience? Drawing on Bauman (1975), the experience of authenticity is to a large extent dependent on the audience's understanding of the performance form. What is the basis on which they evaluate the performance? Whereas a Finnish performance is easier to approach for a local audience that is not quite familiar with the original, Jamaican, context of sound systems, an English performance filled with expressions from dancehall culture requires an audience that appreciates the performance as linked to its original performance context. As the Finnish audience has progressively become more familiar with the performance form, English has become the preferred language for the MCs. During an interview in 2009 in Helsinki, Riina Asamoa - concert promoter and former 
chairperson for the Finnish reggae association - maintains that as MCs have started performing in English, the scene in Finland increasingly resembles its Jamaican counterpart.

However, it has taken some time for the audience in Finland to become accustomed to the particular performative format of the sound systems. During an interview in 2010 in Helsinki, Scandal Bag (Juha Kurkela) and Dublifter (Olli Loikala), both members of the now defunct Cool Runnings Sound System, described the difficulty of trying to present a Jamaican-style sound system performance during the late 1990s in Helsinki and Tampere. According to selector Scandal Bag, it seemed that the audience did not understand what the performance was about as the DJs were, apart from playing records, commenting on the turn of events on the microphone. Scandal Bag remembers that at that time the reaction of the audience was often confused because they were accustomed to a DJ who only plays the records.

Although reggae clubs were already popular in Helsinki during the 1990s, the format of the sound system performance did not become established in Finland until the turn of the millennium when a few sound systems introduced the culture to the audience in Finnish. Asamoa acknowledged especially the efforts of the Komposti Sound System, whose events and music productions have been significant in introducing reggae to native Finns. In addition to revitalizing the live reggae circuit, since the turn of the century the Komposti Sound System has been one of the most actively performing sound systems and concert promoters in Finland. At the time I was conducting my interviews, their weekly club Reggae Sundays was the main venue and meeting place for dancehall and reggae fans in Helsinki.

Henriques (2011: 180) maintains that: "In order to have any influence on the crowd, the MC has to earn their respect". This respect - which essentially determines if an audience believes in the act - can be understood as "cultural capital", as it has been defined in 1979 by Bourdieu (1984) or "subcultural capital" as the concept has been further developed by Thornton (1995) in the context of club cultures. The audience has to believe that the performers have authentic knowledge about the culture and that they know what they are doing. Regarding African-Jamaican culture in Japan, Sterling (2010: 67) notes that an important way performers acquire cultural capital is by travelling to Jamaica. By spending time in Jamaica, sound system selectors and MCs can witness the culture on location and acquire an understanding of it in broader terms. For Sterling (ibid.), in a Japanese context an important trait that an MC acquires from a trip to Jamaica is the ability to speak in a Jamaican vernacular. Although Finnish sound system operators do travel to Jamaica, learning the language does not seem to be as important in Finland, where most people already speak English to a certain degree. The cultural capital gained from travelling to Jamaica is more about having been there, as an act that brings authority. Moreover, as discussions on the Fi-reggae Internet forum indicate, this feature is not always appreciated among the fans. A tension clearly exists between an audience that closely follows what is happening in the Jamaican dancehalls, and an audience that emphasize the local interpretation of the music. The latter reacts against the idea that there is a group of people who supposedly know better how reggae should be experienced because they have encountered the culture in Jamaica. As one writer on the Finnish reggae forum expresses himself about a popular Jamaican recording, which he was not enjoying: "[...] yes, I know my OWN OPINION [original capitals], better than any Jamaican" (Fi-reggae 2009a). It should be recognized that the cultural capital gained through travelling that Sterling (2010) emphasizes also has another side to it, as the conditions for the musical culture are negotiated among the local audience.

Nevertheless, travelling to Jamaica has positive effects on how a performer is perceived by a local audience. Chappa, for instance, noted how visiting Jamaica also inspired him as a performer - giving him energy and enthusiasm to spread this music culture in Finland. Referring to his performance a few weeks before our interview in 
2010, when he had just returned from Jamaica, he observed how his audience also recognized this sense of energy, so that his fresh return from Jamaica could be used to promote the event. He recollects how he was excited about the show and how the audience reacted to his excitement. A feedback loop was established where the performer fed off the audience reactions, who in turn were inspired by the performer's energy. The excitement was also built up before the show on the Fi-reggae forum, which is used to promote reggae events in Finland. Youtube videos of songs that the selectors were planning on playing were linked on the forum and Chappa posted a video he had filmed some weeks earlier in Kingston (Fi-reggae 2010a). To the audience, this suggests not only that Chappa knew through experience what a proper dancehall event is like, but also that the upcoming party in Helsinki would be as exciting and, most of all, as authentic as the street after party in Kingston, Jamaica, that the video portrayed. Several users continued the discussion online the day after the event (Fi-reggae 2010b), thanking the performers for a successful event and noting how Chappa's return from Jamaica had brought new energy to the local context.

The above example illustrates how the MCs, together with their sound system crews, can excite the crowd also outside the performance venue, and how sound systems work as intermediaries of the culture off stage. Sound systems recognize the importance of the local audience and, according to Chappa, one of the most important tasks of the MC during a performance is to "big up" audience members. Chappa told me that he would often call out the names of dancers he recognized in the crowd, which adds excitement to the performance. As the performers acknowledge members in the audience, demonstrating they know who they are performing for, the audience becomes aware of the fact that the performer is as dependant on the audience as the audience is on the performer. Sound systems realize the importance of the audience in the creation of a successful event, and seek to maintain that connection. One might even say, as Thornton (1995: 29) argues about club cultures, that the audience and performer "share the spotlight", as they both participate in the creation of the atmosphere, which becomes the actual performance. Naming the names of not only audience members but also of the artists whose recordings are played at the performance is of importance. As Hebdige (1987: 8) suggests, naming in reggae music is in itself an act of invocation, where the performer pays tribute to the community from which he has sprung and draws power from the names. Calling the names of specific artists is, thus, an act of transferring the credibility of the reproduced artist on to the performer. The sound system MC is a concrete link between the Jamaican performers and the local audience members in Finland.

MC and selector Resupekka (Pekka Lintusaari) from the Turku-based sound system Black Bear Sound confirmed how important it is for him, as a performer, not only to play records but also to communicate with the audience:

Absolutely, I try to connect with the audience. And you can really tell, if you're early in the evening just playing records and then later grab the mic, it really creates a kind of bond between the audience and the performer... That somebody is really there. Especially if you just let yourself go and get into the game, then it's not just a mummy selecting the records in the DJ booth. You are interacting with the audience (2009, Turku).

It could be argued that when the performer is not self-conscious about standing on stage, letting go, he or she adopts the role of the audience and performs the event as a representative of the prevailing ambience at the venue. Henriques (2011: 175) describes the $M C$ in the Jamaican tradition as a disembodied voice in the darkness of the dancehall, but in the Finnish context the MC, like the selector, is often very visible on stage or in the DJ booth, making it easy for the audience to relate with him or her as the embodiment of the prevailing atmosphere. As the MC is guiding the audience through the procession of the event, letting them know about the music played, the task of the MC is not just to inform the audience about what is happening, but to perform the performance situation, which includes the frame that he or she builds around the 
recorded music, which forms the content of the performance, and the overall ambience as part of the event, which is established in an interaction with the audience. Resupekka's stiff "mummy" analogy is descriptive of the position that the performer should not assume - instead, it is important for the MC to function as a representative of the audience, engaging with the party and sharing pleasure with the crowd. The framing of the performance is also tied to the notion of the audience's competence that Bauman (1975) emphasizes, in the sense that the listeners realize sound systems are not just presenting an isolated performance on stage, but seek to create connections between the selector, the music, the sound system and the audience. The audience's competence lies in the realization that they are a part of the performance.

\section{Recordings and the performance content}

Sound recordings evidently provide the main content of the sound system performance. In line with my research questions, rather than focus on individual recordings or their formal musical particularities, here I will concentrate on the performers' strategies regarding the musical repertoire and how their music programming - their selections - affect the localization of reggae. The records that are heard at sound system events almost exclusively fall under the broad category of reggae, and are essentially mostly by Jamaican artists. As Resupekka stated in 2009, compared to average audience members, sound system operators are more attuned to what is happening in Jamaica and know where and how to acquire the latest tunes. Before a reggae record is officially released and more widely distributed via a compilation album or a compiled artist album by a larger record company and available on Itunes for example, recordings are disseminated electronically via promotional lists, blogs, content hosting services and other websites that promote reggae. In order to acquire the music, it is crucial to stay informed about the latest reggae music; this further requires knowledge and understanding about labels, promoters, artists, and producers, plus the relevant connections. Thus, as Resupekka maintained, in terms of finding new music, sound systems function as a "bridge" between the Jamaican music industry and the local audience in Finland. Sound system performances or mixtapes are often the first source of new Jamaican music for local audiences.

However, sound systems do not only perform the most recent music from the Jamaican dance halls. During an interview in 2008 in Helsinki, the selector with MPV sound system, Selecta Andor (Antti Korhonen), explained how he has to balance between presenting the audience with new material - keeping the scene alive and interesting - and at the same time performing familiar, more widely recognized songs. Andor has found that a performance is successful if the balance rests more on familiar material. The latest Jamaican recordings are recognized and appreciated by an insider group, and performing material for them is important in maintaining and proving one's position within the peer community, but in order to start the general crowd dancing, recognizable music is required. Timing is also important in the selection of the most popular tunes; as a sound system gradually builds up the energy of the performance, the audience will eventually increase their participation in the event. Andor illustrates how, through a choice of records, the selector gently builds up the atmosphere:

Usually you start the evening with easier, warm up tunes, for when people are arriving, and just slowly try to get them into the vibe. Then you start thinking about when it would be appropriate to change into something more upbeat. Because, if I have tune that I know will get people on the dance floor, I don't want to play it too early, otherwise people will dance to that tune and then leave the dance floor when it's over. You have to build up the mood slowly to the point when you know people are ready to party, and you learn that from experience. Otherwise you might waste good tunes on an empty dance floor. (2008, Helsinki)

In the age of the Internet, audiences have an increasingly easy access to Jamaican music via services such as YouTube. As a result, the traditional role of sound systems 
as intermediaries of new music has become less important. However, sound systems can substantially influence what becomes popular within the local scene. In a range of ways, they can introduce their musical repertoire to audiences prior to the performances and create a local demand for songs outside their performances. For example, Resupekka described in 2009 how sound systems are able to both advertise performances and make audiences familiar with their repertoire through mixtapes. According to Resupekka, audience members can come up to him during a performance and request songs that they have heard on his mixtape. A few sound systems in Finland also host reggae shows on local radio stations, where they can introduce the music they perform and place it in a broader context. Through these kinds of activities, sound systems can influence local taste and demand for the music.

These processes illustrate how not all music that is popular in Jamaica has the same resonance for audiences in Finland. The music is filtered through sound systems that perform songs that they notice work best in the Finnish context. As Chappa explained in 2010, new dancehall releases that directly comment upon social and political injustice in the Jamaican society or that overall have a more serious message, tend to be less appreciated in Finland, where dancehall is mostly regarded as partyoriented music. Chappa suggested that, in Finland, people perhaps tend to focus less on the lyrics and that songs about serious issues are often also slower and a bit gloomy in mood. The music repertoire that audiences respond to can also vary in different cities in Finland, in tandem with varying performance forms. If a sound system has managed to make a song popular among their regular crowd, it will not necessarily receive the same response in another city with a different crowd.

The locality of individual recordings can further be emphasized through the exclusive dubplates that sound systems commission from reggae artists. Typically, in these recordings a reggae or dancehall singer will sing part of a known song of his or hers, to the same instrumental track but with new lyrics which praise, or "big up", the sound system that has commissioned the dubplate (Manuel and Marshall 2006: 454). The song "Recession" by New York based dancehall artist Beniton the Menace, which became an anthem for the local dancehall scene in Helsinki in the turn of 2008-2009, illustrates this example. The song, which was not particularly popular in reggae communities in other parts of the world, became popular in Finland largely because Komposti sound system was promoting it. Apart from playing the record in their sets in various clubs, it was also frequently featured on their weekly radio show. In early 2009 , Komposti cut a dubplate of the record, which emphasized the song's connection to Helsinki. Komposti Sound's dubplate version of the track, "Beniton the Menace: Recession (DUB)", makes several references to Helsinki.

Apart from naming Komposti sound system and its members (Bommitommi, VG and Enrico) in Helsinki, the dubplate also references several local reggae events, such as Dance pon the Corner, Reggae Sundays, and the venue Redrum where the latter event takes place. Moreover, Beniton the Menace mentions Finnish dancehall dance crew Dancehall Terrorist. The dubplate is thus not only highlighting Komposti sound system as performers, but also drawing attention to important places and people within the reggae scene in Helsinki and therefore resonates well with the local fans. At the same time, as Asamoa maintained in 2009, Beniton the Menace was not well known outside the USA. Through the active promotion of a sound system, the song became an anthem of the local scene in Finland, especially in the city of Helsinki. This not only demonstrates that sound systems influence the musical tastes among listeners in Finland, but is at the same time an indication of a particular local character of the scene and its ability to create local hits.

\section{Localizing the dancehall continuum}

Whereas the first parts in this paper have focused on how sound system performances contribute to the localization of reggae music in Finland, I will conclude 
this study by looking at what is localized through these practices. Here, I am not referring to the actual musical material that sound systems include in their performances, but ideas and values regarding reggae music that these performances entail, endorsing reggae through what I will define here as a dancehall continuum. Theoretically, I draw here on genre rules identified by Fabbri (1982) and Frith (1998), which I use to identify the genre narratives of local audiences. This is done by analysing discussions on the Fi-reggae Internet forum and by considering how reggae initially reached Finland through the global music industry and the genre discourse of rock in the 1970s.

When reggae first reached a broader audience outside Jamaica and its diaspora, it was through the success of Bob Marley and the Wailers in the mid 1970s. Before this, reggae music had spread with the Jamaican diaspora to North America and the UK, where the African-Caribbean community embraced the Jamaican tradition of sound systems as an important cultural institution and entertainment form. When Jamaican records pierced the charts in the late 1960s and early 1970s, they were considered novelty attractions, not taken seriously of the rock press and its mass audience. As Jones acknowledges (1988: 60-61), Jamaican music faced "deep prejudices" by the rock press in the UK, where it was judged to be "boring" and "repetitive". With its base in the sound system culture, as a singles music revolving around individual singers or vocal groups voicing backing tracks assembled by producers and their studio musicians, it did not fit the dominating rock form of the time. As Manuel and Marshall note (2006: 449) records were "produced less for mass public purchase than for use by sound systems".

The music did not meet the genre rules of the global music industry, which Island Records and its manager Chris Blackwell realized as they set out to promote the Wailers as a performing and album recording entity. The process was significant in the popularization of reggae to a broader audience. The Wailers' debut for Island Records, Catch a Fire (1973), became, as Davis (1983: 95) notes, "the first reggae album", in the sense that it was produced and promoted in terms that were more familiar to a rock audience than to a reggae audience that was used to 7 -inch singles. This considerable shift from the Jamaican tradition, both in terms of format and sound, and the repackaging and marketing of the music, lead eventually, as Stolzoff (2000: 97) notes, to a split between the "local dancehall style, associated with DJs and sound system events, and the international style, associated with the Rastafarian-inspired reggae of artists like Bob Marley". This is also how reggae first reached a larger listener group in Finland (Hilamaa and Varjus 2002: 202). Eric Clapton's cover version of Bob Marley and the Wailer's "I Shot the Sheriff" in 1974 became an introduction for many Finns to the music. In that same year a Finnish version of this song, "Taas Nousen Junaan", was released by the established Finnish recording artist Kirka and has been listed as the first reggae recording made in Finland (Bruun et al. 1998: 291).

As reggae was adapted to a larger public outside Jamaica, the experience of reggae in its original context on the island did not change. In Jamaica, sound systems became even more central to the creative processes within reggae and emphasis in the music was increasingly on rhythm and bass, which the international style downplayed. The DJ (the MC) as a performing artist became central to the culture, establishing the stylized form of toasting over records. As Veal (2007: 5) asserts, one of the main differences between the local Jamaican reggae and its international version was in how the audience consumed the music: "As opposed to attending the concerts staged abroad by musicians like Marley and Tosh, most Jamaicans enjoyed music in dancehalls and at outdoor dances at which recorded music was provided by [...] sound systems."

Different ways of engaging with music provide different entries into this musical culture. As Frith (1998: 89) notes, liking a music genre is about engaging in a taste community. The appeal of a specific music culture cannot be detached from an appeal of an ideology, and a set of meanings attached to the genre. Music offers people 
"access to a social world, a part in some sort of social narrative" (ibid. 90). Discussions on the Fi-reggae discussion forum indicate that the narrative through which listeners experience reggae varies. For part of the audience, contemporary styles of Jamaican dancehall reggae are not always well received, or even recognized as part of the reggae tradition. As Will Straw (1991: 373) declares in his influential essay on musical scenes, they often exist in a pressure between "contemporary musical practices, on the one hand, and the musical heritage which is seen to render this contemporary activity appropriate to a given context, on the other". Let us consider the pressure between the popular conception of reggae and the dancehall reggae of sound systems in terms of genre rules, and examine what kind of values regarding reggae are localized through sound system performances in Finland.

One of the most apparent tensions between contemporary dancehall reggae and the internationally popularized reggae is that the former lacks the typical offbeat ostinato that has characterized reggae since its popularization. A large part of the contemporary dancehall performed by sound systems, does not, in Fabbri's (1982: 55) terms, meet the formal or technical genre rule of popular reggae. One user on the Fi-reggae (2009a) forum expresses this concern in his comment: "new dancehall doesn't even sound like dancehall". For the commentator, the dancehall musical style has changed too much for it to even be considered dancehall anymore. As Fabbri (1982: 59) notes, the relative significance of different rules vary from genre to genre. For the reggae fan who enjoys the laid back off-beat reggae groove, the formal structure of the music has a priority over other genre rules, although the ideological value (ibid. 70) associated with reggae from the roots period is also of importance.

Regarding semiotic rules, there are clearly identifiable differences, even possible misunderstandings, in the two genre categorizations I have identified. As Fabbri (ibid. 56) defines semiotic genre rules, they relate to how truth and sincerity are indicated musically - or as Frith (1998: 91) suggests, how different genres read singers as protagonists of their songs. Discussions on the Fi-reggae list (2009a) suggest that while dancehall fans can engage with sexually explicit lyrics, many roots fans condemn such recordings. This can be explained by a different perception of "lyrical realism" (Frith 1998: 91). If the dancehall lyrics are perceived with the same sincerity as that of a Rastafarian singer talking about oppression, the playfulness and humour that dancehall fans identify in the songs can go unrecognised. ${ }^{2}$ One of the most important distinctions between these genre categories, however, can be found in what I would define as the ontological character of the music. This can be understood as a combination of Fabbri's (1982) behavioural and social genre rules, and relates to what is perceived as the main object of critical attention. In a discussion thread on the Fireggae website, a writer under the pseudonym Valtteri declares to have lost hope in reggae and maintains that he has not heard any "good reggae" lately (Fi-reggae 2009b). Consequently, he appeals to the online community to give him suggestions for tunes or artists that might reignite his passion for the music. His peers online are quick to react and several voices express the same concern, while others maintain a more positive position towards new currents within reggae. One user recommends him to visit sound system sessions. While the reply may simply imply that one can hear a selection of good songs at a sound system session, it also articulates the position that sound system sessions should be regarded as the main forum for reggae music. Valtteri, however dismisses this response:

"I rather enjoy my recorded music in an environment where you can hear what kind of soundscape the engineer has created on the record, preferably also without drunkards and other disturbances you might have in a bar" (Fi-reggae 2009c).

Maintaining a preference to enjoy the music in an isolated environment, associating records with domestic, private listening, indicates a clear distinction from the ontology of music in sound system culture. Here, the sound system perfomance, as discussed earlier in this paper, is considered the primary locus for the genre, often regardless of 
the formal genre rules of the music being performed. At the time I was conducting my interviews, most sound systems in Finland performed several different forms of Jamaican dance hall derived music. According to Selecta Andor, a typical event opens with roots reggae, changing towards the end of the night to more contemporary electronic dancehall, and often also including a selection of fast tempo ska or other early forms of reggae. To Andor, this type of performance seemed natural and the way sound systems should perform, as the listener can experience the "whole package" referring to dance hall derived styles.

Following through the line of thought here, I would like to suggest that sound systems localize an understanding of reggae as a dancehall continuum. With a musical continuum, I am here referring to how it has been defined by Simon Reynolds (2009) in his description of the evolution of British dance music from the end of the 1980s, identifying the same sociocultural context of different musical styles. Understanding music genre according to Fabbri (1982), this would suggest that the different musical styles share social and behavioural rules in the sound system performance, but the formal and technical form of the music evolves throughout time. This approach further indicates that the popular roots reggae would be a sub-genre of the dancehall continuum, whereas dancehall, as Sonja Niah Stanley (2005: 56) suggests, is normally understood as part of the reggae continuum. For the dancehall fan, the sound system session is the main forum for the music, and the constantly changing musical styles of the Jamaican dance halls are part of the attraction of the music. In Fabbri's (ibid. 61) terms, constant "transgression" keeps the music interesting to the listener who never quite manages to completely comprehend the codification of the genre.

Furthermore, the "social narrative" (Frith 1998: 90) of the genre, in which the audience participates, is locally created - as discussed above. Returning to the narrative performance theory I have outlined earlier, as Walter Benjamin (1968: 87) suggests, a "storyteller takes what he tells from experience - his own or that reported by others. And he in turn makes it the experience of those who are listening to his tale". The task for sound systems is thus not only to narrate Jamaican dancehall culture as an experience of others, but also to create a context for it. As we have seen, sound systems do not simply inform audiences about the Jamaican music being reproduced, but perform the music as part of the prevailing atmosphere that they create together with the audience. Similarly, Bauman (1986: 5) suggests that narratives are not to be viewed as icons of occurred experiences. On the contrary, a narrative can be seen to create the proceedings it refers to - whether they have occurred or not. According to Bauman "events are not the external raw materials out of which narratives are constructed, but rather the reverse: Events are abstractions from narrative". In other words, sound systems themselves create a narrative, a local understanding and local experience of the dancehall culture they seek to convey. The performance is not about representing a replication of Jamaican dancehall culture as such or providing the listeners an entry into that culture, but about presenting the audience with an abstraction or an idea about the intermediated culture and creating a unique narrative about it on location.

\section{Conclusion}

This study has discussed how certain aspects in the performance practices that are associated with sound systems can contribute to the localization of reggae music in Finland. Having focussed on the activities of local Finnish sound systems, especially the role of the $\mathrm{MC}$, and theorized the performance as an act of storytelling where the performers convey the folklore of Jamaican dancehall culture in Finland, the study shows how the performance depends on the interaction between the performers and the audience, negotiating a local understanding of reggae music. An important link between the local setting and the artists heard on the records is the use of special dubplate recordings. These unique mixes of recordings create conceptual and concrete 
links between the Finnish locality of the performance and the dancehall culture in Jamaica.

This study has shown how through these processes particular values regarding reggae as a genre are localized. I have defined this understanding of reggae as the dancehall continuum, which views the culture of the Jamaican dance halls as an evolving musical culture, linking different musical styles together through their relation to sound system performance. Compared to how reggae was initially popularized outside Jamaica and its diaspora through the global music industry as the Rastafarian inspired roots reggae, the grass roots localization of reggae through sound system performances reflects more the contemporary dancehall culture in Jamaica. The activities of local sound systems also engage the local audience to participate in the creation of a local narrative about dancehall culture. Thus, the study illustrates how not all music that is popular in Jamaica has the same resonance for audiences in Finland. The music is filtered through sound systems that stimulate unique interpretations and that, together with their local audiences, negotiate the sounds of their local scenes.

In brief, this study has attempted to provide an entry into understanding the processes of cultural localization and signals the important role that local actors play in developing a distinctive local interpretation of reggae music. It has done so by focussing primarily on the localization process from the performers' perspective. Several threads are to be explored further regarding the adaptation of dancehall culture in Finland. Since 2008-10, the period of my interviews and forum research, reggae music has continued to develop in Finland - for example, with the emergence of Jukka Poika as popular performer on a national scale, reaching platinum sales with his album Kylmästä Lämpimään in 2011 and double platinum sales with the subsequent Yhdestä Puusta album in 2012 (IFPI Finland). Reggae has increasingly spread outside the sound system circuit; dancehall can now be heard in a number of clubs that are not specifically reggae-oriented. Moreover, choreographed dancing in a Jamaican style has increased in importance within the dancehall scene, where several dance crews have now emerged and annual dancehall king and queen contests are held. As a result, dancehall can now be found as part of the curriculum of several dance schools in Helsinki. These are some of the factors that continue to affect the ongoing localization process of reggae and dancehall music in Finland that future research on the subject could consider.

\section{Endnotes}

1 Henriques also identifies championing as one of the MC's tasks, relating this feature specifically to soundclashes, which I am not concerned with in this study.

2 The role of the sexually explicit lyrics in dancehall culture has been heavily debated (Niah Stanley 2005; Stolzoff 2000; Cooper 2004) and would require further investigation in the Finnish context.

\section{References}

\section{Bibliography}

Barrow, S. and Dalton, P. (2001) Reggae: The Rough Guide. London. Penguin Books. Bauman, R. -

(1975) Verbal Art as Performance. American Anthropologist (77/3): 290-311.

(1986) Story, Performance and Event. Contextual Studies of Oral Narrative. New York: Cambridge University Press.

Benjamin, W. (2007 [1968]) The Storyteller. In Hannah Arendt Ed. Illuminations. New York: Schocken Books: 87-91. 
Bourdieu, P. (1984) Distinction. A Social Critique of the Judgment of Taste. Cambridge: Harvard University Press.

Bradley, L. (2001) This is Reggae Music: The Story of Jamaica's Music. New York: Grove Press.

Bruun, S. et al. (1998) Jee Jee Jee. Suomalaisen Rockin Historia. Porvoo: WSOY.

Cooper, C. (2004) Sound Clash: Jamaican Dancehall Culture at Large. New York: Palgrave Macmillan.

Davis, S. (1983) Bob Marley. The Biography. London: Arthur Barker Ltd.

Fabbri, F. (1982) A Theory of Musical Genres. Two Applications. In David Horn and Philip Tagg Eds. Popular Music Perspectives. Göteborg and London: IASPM: 5281.

Fi-reggae -

(2009a) On Dancehall and Daggarin. http://www.fi-

reggae.com/read.php?5,235978,page=1 Accessed 27 February 2013.

(2009b) Tukiryhmä uskonsa menettäneille. http://www.fireggae.com/read.php?10,251788,page $=1$ Accessed 27 February 2013

(2009c) Re: Tukiryhmä uskonsa menettäneille. http://www.fireggae.com/read.php?10,251788,page=2 Accessed 19 April 2013

(2010a) DANCEHALL GOOD TO WE - 12.2.2010 @ REDRUM (HKI). http://www.fireggae.com/read.php?6,255070,page=1 Accessed 27 February 2013

(2010b) DANCEHALL GOOD TO WE - 12.2.2010 @ REDRUM (HKI). http://www.fi-reggae.com/read.php?6,255070,page $=2$ Accessed 27 February 2013

Frith, S. (1998) Performing Rites: Evaluating Popular Music. Oxford and New York: Oxford University Press.

Hebdige, D. (1987) Cut N Mix. Culture, Identity and Caribbean Music. London: Comedia.

Henriques, J. (2011) Sonic Bodies: Reggae Sound Systems, Performance Techniques and Ways of Knowing. New York: Continuum.

Hilamaa, H. and Varjus, S. (2002) Reggae OK in Lindfors et al. Eds. Suomi Soi 2. Rautalangasta Hiphoppiin. Hämeenlinna: Tammi: 202-203.

Jones, S. (1988) Black Culture, White Youth: The Reggae Tradition from JA to UK. London: Macmillan.

Kaski, T. and Vuorinen, P. (1984) Reggae Inna Dance Hall Style. Helsinki: Black Star.

Katz, D. (2003) Solid Foundation: An Oral History of Reggae. New York: Bloomsbury

Manuel, P. and Marshall, W. (2006) The Riddim Method: Aesthetics, Practice, and Ownership in Jamaican Dancehall. Popular Music (25/3): 447-470.

IFPI Finland: Musiikkituottajat - Tilastot - Kulta- ja platinalevyt http://www.ifpi.fi/tilastot/artistit/jukka+poika Accessed 29 November 2013

Niah Stanley, S. (2005) 'Dis Slackness Ting': A Dichotomizing Master Narrative in Jamaican Dancehall. Caribbean Quarterly (51/3): 55-76.

Reynolds, S. (2009) The Hardcore Continuum: Introduction. The Wire. Issue 300, February 2009: http://www.thewire.co.uk/in-writing/essays/the-wire-300_simonreynolds-on-the-hardcore-continuum_introduction Accessed 1 March 2013

Sterling, M. D. (2010) Babylon East: Performing Dancehall, Roots Reggae, and Rastafari in Japan. Durham and London: Duke University Press.

Stolzoff, N. (2000) Wake the Town and Tell the People: Dancehall Culture in Jamaica. Durham and London: Duke University Press. 
Thornton, S. (1995) Club Cultures: Music, Media and Subcultural Capital. Cambridge: Polity Press.

Veal, M. E. (2007) Dub: Soundscapes and Shattered Songs in Jamaican Reggae. Middletown: Wesleyan University Press.

\section{Interviews}

Riina Asamoa (2009) interviewed by Kim Ramstedt, Helsinki. 5 September, Antti 'Selecta Andor' Korhonen (2008) interviewed by Kim Ramstedt, Helsinki, 16 February.

Pekka 'Resupekka' Lintusaari (2009) interviewed by Kim Ramstedt, Turku, 28 April. Juha 'Scandal Bag' Kurkela and Olli 'Dublifter' Loikala (2010) interviewed by Kim Ramstedt, Helsinki, 6 May.

Mikko 'MC Chappa' Näppä (2010), interviewed by Kim Ramstedt, Helsinki, 20 February.

\section{Discography}

Eric Clapton (1974) "I Shot The Sheriff", RSO Records, US.

Jukka Poika (2010) Kylmästä Lämpimään, Suomen Musiikki, Finland.

Jukka Poika (2012) Yhdestä Puusta, Suomen Musiikki, Finland.

Komposti Sound (2009) "Beniton the Menace: Recession (DUB)", Komposti Dubs, Finland. Streamed http://www.myspace.com/kompostisound - Accessed 12 December 2013.

Kirka (1975) "Taas Nousen Junaan", Tiukka Linja, EMI Finland, Finland.

The Wailers (1973) Catch a Fire, Island Records, April, UK. 